\title{
Papers
}

Explorations into Children's Literature

\section{Rules and Rhizomes: A Mary Poppins Sampler}

\section{Margaret Mackey}

When the Disney movie of Mary Poppins was released in 1964, I was a teenager and far too cool to watch it under the aegis of my own identity. But as a long-term devotee of the books I was keen to see what Disney had made of this adaptation, so I borrowed the children of some family friends as camouflage and headed for the cinema. To my dismay, Julie Andrews was too pretty, too sweet, too twinkly, and too insipid to suit my sense of the stern nanny, and I found the story diminished as a consequence.

Kathryn Hughes, on the other hand, was eight years old and already a huge fan of the movie when she first read the books by P.L. Travers. She was initially thrilled to unwrap a book of Mary Poppins but her delight quickly turned to deep dismay. Her first reaction was that she had been given some kind of counterfeit. The picture on the cover was simply wrong:

This Mary Poppins looked nothing like the soft and lovely Julie Andrews. In fact, she resembled a stiff peg doll, thin and hard, with a peg nose and two spots of high colour on her wooden cheeks. This was the kind of nanny, magical or not, from which any sensible child would shrink. (2013, n.p.) 
Things deteriorated as she read further: 'My suspicion grew that I had been palmed off with inferior goods' (2013, n.p.) The print book was dull, and Hughes was frustrated because the stories did not wrap up tidily:

there were long waffly passages in which characters who didn't appear in the Disney film went on and on about the stars, and the wind and the moon and the Grand Chain that connects all creatures. Even the adventures that Mary Poppins undertakes with her charges had an indeterminate quality, without a proper resolution. At the end of each outing Jane and Michael go to bed not sure what has just happened or what it all means. And the same was true of eight-year-old me. Disgusted, or perhaps disturbed, I tucked Mary Poppins on to the 'too difficult' section of my small library and moved on to Paddington Bear. (2013, n.p.)

My own teenage dissatisfaction with the Disney version of a much-loved series was a relatively trivial affair; I simply maintained allegiance to the print Poppins. The younger Kathryn Hughes was clearly much more shaken by the difficulties of making the transition in the other direction, from movie to book.

We live in a cultural world where discrepant versions of much-loved characters are commonplace, and yet we do not really have a useful vocabulary for exploring the impact of such contradictions. This article investigates some possible terminology through an exploration of some of the twists and turns in the saga of Mary Poppins. In perusing this landscape, I first return to Pullman's idea of the phase space (Pullman 1998; Mackey 1999, 2006). Second, I explore the explanatory potential of the horticultural metaphor of the rhizome as further explicated and enhanced by Deleuze and Guattari (1987). I place these 
reflections in the context of variant versions of Mary Poppins. In an era where the author's life is often appropriated into the commodification cycle, I also investigate the biography of P.L. Travers and its relationship to the works she created and/or resisted.

We are so used to a world of proliferating adaptations and commentaries on those new versions, not to mention stories licensed for seemingly endless commodification, that some of the effects of such plurality on young readers become invisible to us, a taken-for-granted landscape of reading. Our current cultural arrangements affect childhood reception in different ways, and it is important to pay attention.

\section{A cultural schema}

I begin with a brief overview of the major renditions of Mary Poppins. The magical nanny is instantly recognisable as she flies holding her parrot-handled umbrella. Once landed, she takes children out of ordinary daily life into magical adventures, while presenting a domestic front of no-nonsense sternness. The initial version of Mary Poppins is the nanny in the books conceived and written by P.L. Travers over a period of more than fifty years. This character changes very little through the decades; she is sharp-tongued and demanding, and invariably denies every magical experience with a sniff and a snort. Travers experimented with some spin-offs, but did not make any important alterations in the essence of the character she first presented in 1934 and last re-visited in 1988.

The book Mary Poppins blows into Cherry Tree Lane at a moment when the Banks family is desperately in need of a nanny. She is accepted into the family with little cross-examination from Mrs. Banks (not Mr. Banks, as later re-workings suggest; he has nothing to do with the 
hiring). Immediately, she manifests her uniqueness by sliding up the banister, and unpacking a huge number of bulky items out of her apparently empty carpetbag. Thus introduced, Mary Poppins takes the children in her charge on mundane outings that lead into a riotous set of alternative universes. When the children and their nanny return home, however, she invariably refuses to acknowledge that any such adventure has taken place. There is little change in this narrative approach throughout the books, though the final volume is less episodic in its structure.

It is unusual but not unheard-of for an author to sustain such an extended series of books over many decades. What makes Mary Poppins an intriguing case study is the uneasy relationship with an almost equally long-lived adaptation. The 1964 Walt Disney film and the title character portrayed by Julie Andrews occupy a definitive place in contemporary culture. This character has now also been around for more than 50 years.

The two versions of the personality of Mary Poppins have each survived, more or less intact, although the more sentimental Disney character is certainly better known today. A stage musical $(2004,2006)$ attempts some reconciliation of the two incarnations, drawing on the Disney songs while making more substantial use of events from the books. Recently, a major film actually made a plot out of the discrepancies. Saving Mr. Banks (2013) may be highly slanted in favour of the Disney version but it does raise very interesting questions about who 'owns' a fiction and what 'authorises' it. This issue of 'ownership' is rendered even more fascinating in the Mary Poppins saga because of some idiosyncrasies of the author, who fictionalised herself and was later fictionalised by others. 


\section{A partial Poppins chronology}

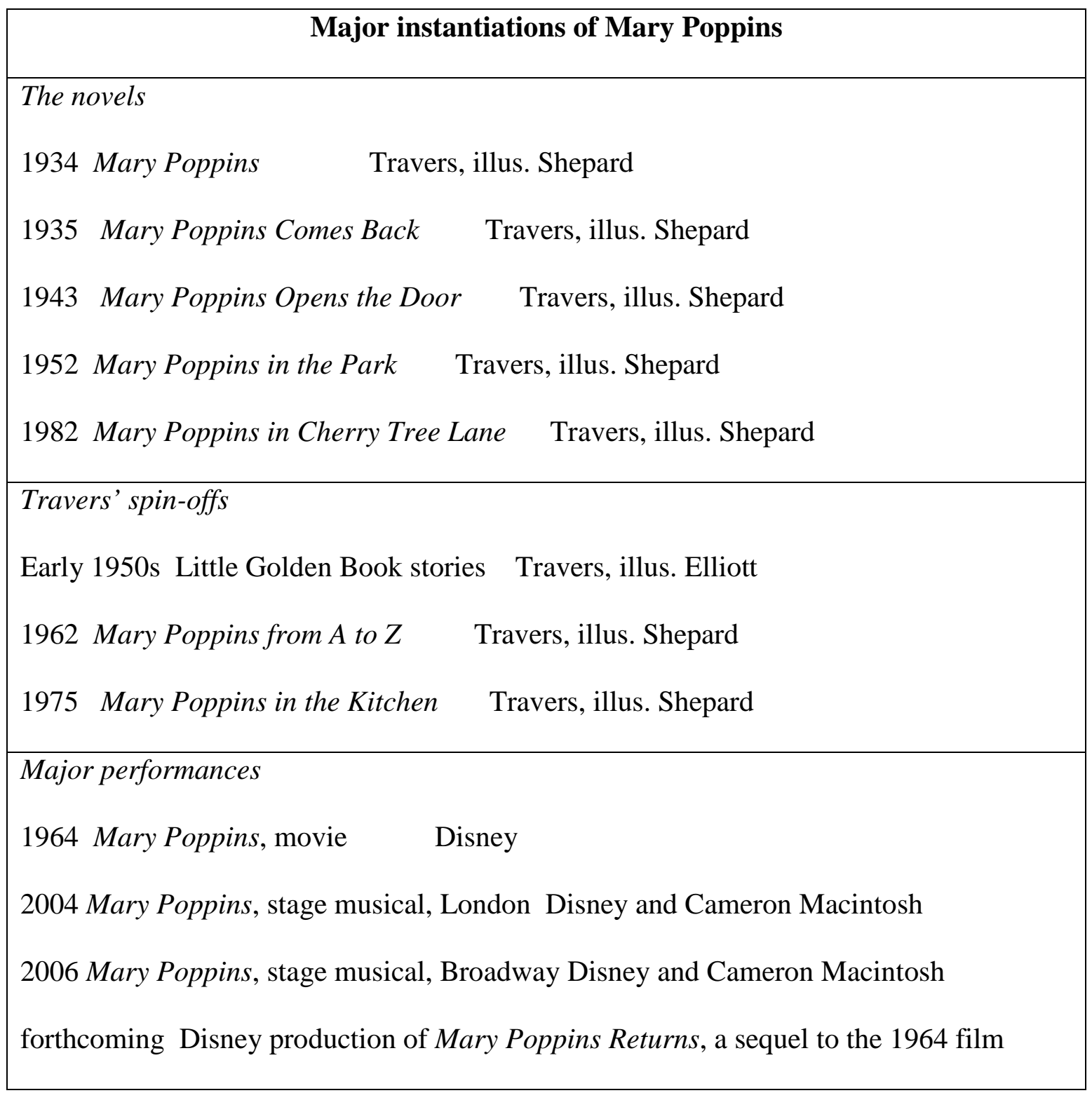

The pluralisation of a singular fiction is not a new phenomenon. Reworkings of old stories are at least as old as the history of drama. They proliferate in contemporary culture and learning readers find ways to manage them. An adaptation can never and should never produce an exact replica of a text, and we expect some elements to shift in a new version. Fidelity is only one consideration in such a mutation, and audiences vary in their definition of what makes an intolerable change in a story. In this particular example, the Disney Mary 
Poppins introduced at least two significant distortions: a kind of imposter syndrome in the main character, and an over-determined ending imposed on a cyclical narrative. In this article, I consider cultural attitudes about whether there is a borderline between metamorphosis and mutilation, focusing mainly on the issue of the ending of the story as expressed through the story of Mr. Banks, since the question of Mary Poppins' character has been thoroughly canvassed elsewhere (e.g., Pearce 2015; Levin 2007; Elick 2001; Szumsky 2001.

As a starting point to this discussion, it is worth noting that, although the eight-year-old Hughes was puzzled by the discrepancies in Mary Poppins' character, it was the contradictions of the perceived necessity to 'end' the story that really defeated her. The insertion of the successful reform of Mr. and Mrs. Banks into loving and attentive parents marks a major Disney alteration, whose impact is far-reaching. Reception is seriously complicated by the introduction of a happy ending to an ambivalent story; it is challenging to unpick it and return to an indeterminate state, even if an open ending was essential to the originating fiction. Exploring these contradictions may open new ways of thinking about adaptation and reception.

Travers was not happy with Walt Disney's rendition of Mary Poppins. Audio recordings survive of her many suggestions for improvement, in discussion with the Sherman brothers, who created the songs that are indelibly associated with the movie. These recordings ground an essential plot element in the meta-story of Mary Poppins presented in the 2013 film, Saving Mr. Banks. Travers left the première in tears (the Disney version is that they were tears of acceptance and catharsis but this verdict is disputed by people who knew her at the time or talked with her later). She placed strictures on any later staging that confirm her 
unhappiness with at least some elements of the Disney production, stipulating in the contract for the London stage musical that "no American would be allowed to participate in its making' (Rochlin 2013).

The success of the Disney film is clear: it has triumphed on every form of family screen for more than half a century. The stage production has similarly won awards and attracted large audiences. Yet Travers' print Poppins has also survived successfully.

\section{Adaptation and reception}

Can a theoretical investigation improve our understanding of this phenomenon of contradictory versions? We could establish a dichotomy of the aesthetically grounded and literary Mary Poppins and the capitalist movie alternative (though Travers unquestionably had her own money-making ambitions for her books so it is far from being a pure binary). To write off the Disney version as a mere money-spinner, however, would be to dismiss its own valid artistic achievements. It is troubling as an adaptation, but as a film on its own (sentimental) merits, it has much to offer to young viewers. The songs are catchy; the story is coherent; and Mary Poppins' magic ways are as seductive in this format as in any other.

Linda Hutcheon talks about those readers or viewers who are familiar with both an original and its adaptation(s) as knowing interpreters (2006, p. 120). They make sense of a story in a palimpsestic way, she suggests, overlaying their knowledge of the different versions. The knowing viewers of Disney's Mary Poppins are in some ways at a disadvantage; for many of them the additional information provided by the palimpsest of Travers' novels is a distraction. Being aware that Mary Poppins 'should' not be so jolly and kind-hearted 
prevents them from engaging with the many elements of this movie that develop its overall narrative and aesthetic coherence, if - and only if - the Travers version remains in abeyance. Any attempt to perceive the subtleties and mythological connotations that pervade the novels is doomed to frustration. Yet the movie was reviewed very positively on its release, and fifty years of child devotees suggest that Disney got something right. And the failure of the palimpsest can work in the opposite direction as well, as Hughes' graphic account describes.

I am interested in these discrepancies and their consequences at the level of reception. How do we think about divergent versions of a story beyond the limits of considering one simply as an unproblematic rendering of the other? It is misleading today, after half a century of the movie's relatively autonomous life, to consider it as a mere dependent appendage of the novels. Yet the link still demands attention. Are there useful ways of describing such a complex relationship?

Examples from the Mary Poppins oeuvre and from assorted renditions of the life of P.L. Travers illustrate two possible theoretical approaches to the thorny question of adaptations that develop lives of their own: the phase space and the rhizome.

\section{Phase space questions}

Philip Pullman makes metaphorical use of the concept known in the field of dynamics as a phase space: 'the untrackable complexity of changing systems. It's a notional space which contains not just the actual consequences of the present moment, but all the possible consequences' (1998, p. 47). A phase space for a game of noughts and crosses 'would contain every possible outcome of every possible initial move, and the actual course of a 
game could be represented by a path starting from the one move that was actually made first - a path winding past numbers of choices not made' (1998, p. 47). The actual choices create a singular story; the plural world of possibilities not explored remains in the shadow-world of the phase space.

Pullman's account of the phase space lets us explore how adaptations may draw not only on the elements actively portrayed in an originating text but also on the alternative options of the phase space - the 'playable' moves that, in the author's creation, were not played, so to speak (Mackey 1999, p. 2006). On Pullman's reckoning, the phase space will contain only those unplayed choices that are valid for a particular world. 'There are rules,' he says (1998, p. 45). The rules make the game of pretending enjoyable; 'the complete freedom of our play is held together and protected by this armature of rules' (1998, p. 46).

An adaptation often draws on the logic of such phase space elements to enrich a new incarnation of a story, adding or subtracting elements that accord with the phase space of the original. Audiences may ask themselves if an adaptation matches what happens in the original text. They may also tacitly check their larger sense of the story to see if the new version could be imagined as relating organically to the phase space of the originating story.

To explore an example of an interpretive shift that does not matter very much, Travers gave Mr. and Mrs. Banks four children, later five; Disney cut that number back to two. Many readers and viewers have no trouble with such a change; a film is usually smaller than a novel and such economies of scale (and of budget) can be readily defended in terms of artistic focus. In both cases, there are more children than the parents feel able to care for themselves, 
and they are delighted when help arrives unexpectedly at the door; the essential ingredient of the parents' desperation for assistance provides a connection between the two renditions of the story that passes the phase space test. In all versions, Jane and Michael are the two focal children and it is usually their perspective that is communicated.

Can a phase space play a role in assessing the legitimacy of an adaptation? I submit that many 'knowing' interpreters overlay their sense of the phase space created by one text or another, to enrich their developing understanding of a textual world created in a variety of versions and formats. When an adaptation includes fictional information that can never accord with the original or its phase space, these knowing interpreters must find ways of living with discrepancy. Some people simply do not care, but others are deeply troubled or annoyed.

Take, for example Mary Poppins' attitude to medicine. The book and the film versions separate in ways that seem to me to be irrevocable. Here is the start of the scene in the book version:

'Is that your medicine?' enquired Michael, looking very interested.

'No, yours,' said Mary Poppins, holding out the spoon to him. Michael stared. He wrinkled up his nose. He began to protest.

'I don't want it. I don't need it. I won't!'

But Mary Poppins' eyes were fixed upon him, and Michael suddenly discovered that you could not look at Mary Poppins and disobey her. There was something strange 
and extraordinary about her - something that was frightening and at the same time most exciting. (Travers 1965/1934, pp. 21-22)

Michael eventually discovers that the medicine is delicious (and different from Jane's), but Mary Poppins cuts him no slack at the outset. In contrast, Julie Andrews softens the blow of the medicine in advance, singing, 'Just a spoonful of sugar helps the medicine go down' (Sherman \& Sherman, 1964).

This idea of the phase space helps me understand why I find the Disney film so jarring, even as I acknowledge its significance to generations of young people and their parents. The softhearted Mary Poppins that Disney and Andrews created simply does not fit any part of the phase space of the Travers world. Disney's Mary Poppins can be stern but she is not frightening in the primal way that Michael almost immediately discovers in the book.

The stage musical of Mary Poppins, which debuted in London's West End in December 2004 and on Broadway in November 2006, offers a third version. The story, according to a note from the London Theatre Guide of December 2004, was 'cleverly adapted by Julian Fellowes from both the film persona of Mary Poppins and the one created in the books by Poppins' author Ms Travers (Bird 2004, n.p.) A 2006 Broadway review suggests that 'the re-creators of "Mary Poppins" have said they wanted to restore Ms. Travers's original sensibility, including a mysticism that is by no means pure Church of England' (Brantley 2006, n.p.)

A 2016 review of a revival of the Broadway version helpfully sums up the changes:

Many (but not all) of the movie songs were kept and new songs added. More characters from the first two Poppins books were included along with their stories, 
like the Banks family's lazy odd-jobs man, Robertson Ay, ancient Mrs. Corry who sells sweets and words like Supercalifragilisticexpialidocious), Mr. Banks' childhood nanny, Miss Andrew, and some park statues that come to life. If you're a fan of the Disney film, you'll find it jarring that the movie songs are often used in very different places and contexts in the stage musical. (Overton 2016, n.p.)

The 'Spoonful of Sugar' sequence is moved to a different place in the stage story. Jane and Michael are more vigorously naughty children in the play, and they destroy the Banks family kitchen. Mary Poppins sings 'A Spoonful of Sugar' as she helps them restore order, a clever reworking of a song that could not possibly be left out if the show were to appeal - or even appear credible - to 'knowing' fans of the movie.

But it is the minor character of Mr. Banks who perhaps offers the most interesting opening to phase space consideration - in part because of his role in the ending that Disney inserted into this cyclical saga. Throughout the books, Mr. Banks changes very little. He is mostly an absentee father, off at work 'making money' by cutting out threepenny bits (Travers 1965/1934, p. 14). Occasionally we learn a bit more about him: he loves stars and is interested in astronomy; his childhood nanny, Miss Andrew, was very frightening. But overall, his character is flat, and it seems reasonable to suggest that his phase space is correspondingly small.

Does a blank offer license for infilling at will? Disney enlarged the character of Mr. Banks and allowed him to learn valuable life lessons from Mary Poppins (about seizing the moment, enjoying your children's childhood, and flying kites). In an interview conducted in 2013, 
Richard Sherman is nonchalant about adding a heavy-duty plot ingredient, clearly regarding it as a simple improvement:

'When we first read the books, we thought "There's no story here. We have to tell the story," [sic] he says. "There's a reason Mary Poppins comes. It's because it's an unsettled household. The father's paying no attention and the mother is off with the suffragette movement. This is stuff we trumped up." (quoted in Newman, 2013)

Sherman provides a slightly more detailed account of the same pivotal moment, in a New Yorker article published in 2005:

'We had to come up with a need for Mary Poppins to come to the Banks family,' Richard Sherman told me recently. 'We had to make her a necessary person.' Their first thought was to get rid of Mr. Banks. 'We were going to set the thing during the Boer War and have his regiment called up,' he said. 'Then you could have had a real happy ending, when he came home.' And then, Sherman said, they had an inspiration: 'You could make the father emotionally absent.'

(quoted in Flanagan 2005, n.p.)

Both these interviews suggest that the Shermans, rather than Travers, were responsible for inserting the theme of paternal inadequacy into the story in the first place. In the 2005 account, Mr. Banks' failings seem to be perceived by his secondary creator as a simple form of plot engine.

The stage play added further background understanding of Mr. Banks, but its phase space accords more tightly with that of the film rather than the books. Brantley raises this point in his 2006 review: 
'Mary Poppins' as a study of an unhappy family in need of healing comes more from the Disney movie ... than from the Travers stories. . . . The show's most significant progression isn't about the children, but about Mr. Banks, who learns to stop recoiling when his wife tries to kiss him and to value quality time with the kids over making money.' (Brantley 2006, n.p.)

Travers' unchanging cipher of the character of Mr. Banks is less sentimentally oriented towards self-improvement, and I personally prefer his limited role in the story. But questions of phase space involve more than issues of taste: 'There are rules' (Pullman 1998, p. 45). There is so little information about Mr. Banks in the books that most of the developments in the film and musical are not actively contradicted by anything Travers created. He could have had a difficult childhood (Miss Andrew is a certifiable horror in the novels). We know from the books that he is harried by the need to support his family; he could be open to developing some wistful awareness that he is ignoring the elements that give his life true value. And yet, the evidence is not convincing.

Take, for example, his role in 'The Bird Woman,' Chapter Seven of the print Mary Poppins. He offers an invitation to Jane and Michael to visit him in the City, saying to Mrs. Banks,

'My dear, if it doesn't rain I think Jane and Michael might call for me at the Office today - that is, if you are agreeable. I have a feeling I should like to be taken to Tea and Shortbread Fingers and it's not often I have a Treat.' (Travers 1965/1934, p. 115)

This invitation is offered prior to the point in the story where the Disney version shows Mary Poppins reforming Mr. Banks. Furthermore, on their way up Ludgate Hill, the children discuss whether the Bird Woman will still be feeding the birds on the steps of St. Paul's. It is 
very clear that they have made this trip many times before, and that their father has entertained them in the City on previous occasions. But Mr. Banks does not appear again in the chapter; his role is confined to inciting the incident. He does not need to develop or change into a more sympathetic character.

At the very end of the print Mary Poppins, Mr. Banks is once again a no-show. He features at the start of the final chapter: he sings in his bath because it is the first day of spring, he throws the household into a tizzy because he has lost his briefcase, and he makes the pregnant observation that the wind has shifted to the West. But in the uproar that follows Mary Poppins' departure, he is simply missing. It is left to Mrs. Banks to utter the (highly unreformed) lament:

'Really, children, really! I don't understand you. Do be good, I beg of you. There's nobody to look after you tonight. I have to go out to dinner and it's Ellen's Day Off. I shall have to send Mrs. Brill up.' And she kissed them absentmindedly and went away with an anxious little line on her forehead. (Travers 1965/1934, p. 219).

The final sentence of the book clearly demonstrates that the children are left to comfort each other: Jane 'tucked him in just as Mary Poppins used to do. .' (1965/1934, p. 222). The book concludes with that recognised signal of open-endedness, an ellipsis. This ending is very far from sentimentally conclusive, in contrast to how the kite-flying song wraps up the movie version.

Not everybody minds. Critics, audiences, and award committees have all responded rapturously to both the movie and the musical versions of Mary Poppins. Saving Mr. Banks 
was more ambivalently received, but for the less knowing viewer, it too offers a persuasive, if sentimental, story. Clearly, distorting the phase space of a fiction does not doom an adaptation to ignominy. Pullman describes an organic aesthetic experience where 'rules' operate in the development of cohesion. The development of Mary Poppins operates on a more 'unruly' basis.

\section{The concept of the rhizome}

If the phase space prescribes a coherent fictional universe, operating by narrative 'rules,' perhaps the idea of the rhizome may offer a route into more explicit consideration of the paradox that fuels the 'related but contradictory' strands of Mary Poppins. The unruliness of the fictional collective of instantiations of Mary Poppins may be more precisely captured in both horticultural and theoretical accounts of the rhizome.

Here is a definition of the rhizome that comes out of the world of gardening: 'Rhizomes are horizontal underground stems that strike new roots out of their nodes, down into the soil, and that shoot new stems out of their nodes up to the surface . . . a form of plant reproduction' (http://landscaping.about.com/cs/lazylandscaping/g/rhizome.htm). Deleuze and Guattari apply this definition metaphorically. They suggest that the rhizome exists in a permanent state of in medias res: 'It has neither beginning nor end, but always a middle from which it grows and which it overspills' (1987, p. 21). Educators, exploring the idea of rhizomatic learning, provide expansive and forceful adjectives: the irrepressible rhizome is chaotic, aggressive, resilient, and invasive (http://rhizomatic.net). 
To what extent does the disruption implied in these descriptors apply to a story that is subjected to the Disney machine? The nature of the root system suggests that there are undeniable connections between different manifestations of a rhizome, but it does not appear to be open to the same kind of orderly analysis that a phase space approach might mandate. Does this more assertive and chaotic metaphor offer a better understanding of the processes that have given us the contradictions of the Mary Poppins world? And if so, what are the effects on reception?

\section{No beginning and no end}

Travers published Mary Poppins in 1934. Surely this statement provides a beginning that must count as definitive in the normal order of language. Yet it is possible to make the case that the story and the character joined an ongoing mythological conversation, rather than making a new start. The authorial persona also emerged full-blown into the middle of the author's ongoing biographical span.

P.L. Travers was born in Australia as Helen Lyndon Goff, and remained there until she was

24. She renamed herself Pamela Lyndon Travers and moved to England, with occasional stays in the United States; she also inserted herself, on relatively thin grounds, into a romantic Irish literary heritage. She regularly lied about her age and deceived close friends into thinking she was British. In effect, she invented a new version of herself in the middle of her life. And her invention was substantial: she is possibly the only author in history to have had serious consultation about her writing both with W.B. Yeats and with Walt Disney. 
Travers claimed to have developed Mary Poppins out of an amalgam of assorted pre-existing mythologies. In 1978, she wrote, 'I have always assumed, when I thought about it at all, that [Mary Poppins] had come out of the same well of nothingness as the poetry, myth, and legend that had absorbed me all my writing life' (Travers 1999/1978, p. 177). The books supply many hints of Mary Poppins' venerable past. She is known and respected by fairy tale characters, mythological heroes and heroines, constellations, and statues. In short, she is legendary. Travers, talking about writing for children, says,

It is all endless and all one. And from time to time, without intention or invention, this whole body of stuff, each part constantly cross-fertilizing every other, sends up what is the right word? - intimations. And the best you can do, if you are lucky, is to be there to jot them down.

(1999/1978, p. 182).

The book character of Mary Poppins seems to step out of a mythological past; similarly, her story does not reach a definitive conclusion. Unlike the movie Mary Poppins, she makes no permanent mark on the Banks household. Life is easier when she is present, and they miss her when she is away, but she does not effect any enduring alteration of the family dynamics that continue in her absence. Furthermore, after the third book, Travers is explicit that she is no longer adding to the chronology of Mary Poppins' ongoing visits to the Banks family; she is inserting stories into the accounts of previously established sojourns. In a foreword to Mary Poppins in the Park, she says, 'The adventures in this book should be understood to have happened during any of the three visits of Mary Poppins to the Banks family. ... She cannot forever arrive and depart' (2010, p. 503). 
In Disney's Mary Poppins, the reshaping of the story of Mr. Banks interferes with this vague chronology. Thus one major rhizomatic outbreak of the Poppins world inserts a singular ending (inadequate parents shape up) into a story that began in a much more cyclical, plural, and rhizomatic form. Apart from the addition of baby Annabel mid-way in the saga, the print Mary Poppins comes and goes in a largely static world. Disney added features of moral improvement, at least for the secondary characters of the parents, in the 'stuff we trumped up' in the studio (Mary Poppins, being already practically perfect in every way, defied even Disney in this respect). If the movie Mary Poppins 'came back' to a logically designed sequel, she would surely discover that there was little left for her to do.

Saving Mr. Banks provides a metafictional gloss on the two versions of Mary Poppins and impertinently sets out to 'save' both Mr. Banks (already a fictional character) and his author (now cast as another fictional character, simply at a different level of world-making). Both Mr. Banks and P.L. Travers are Disneyfied in this concoction, in which Travers sets out to resist the Hollywoodisation of her character but eventually succumbs to Disney's assessment of the importance of the reformable father, and sheds tears of acceptance at the première of the movie. The story is based on the real-life Travers' encounter with the Sherman brothers and their exegesis of the proposed film, and draws on tape recordings of their joint sessions over a couple of weeks in 1961. Short clips of the recorded voice of the real Travers play out the credits at the end of the movie. 
The sweetened impact of Saving Mr. Banks both draws on and affects different biographical works about Travers. I was interested to find two online listings for a biographical film about Travers, made by the Australian Broadcasting Corporation. In 2002, ABC advertised The Shadow of Mary Poppins and described it as 'the story behind the fictional legend. . . without the spoonful of sugar.' By 2014, however, the ABC produced an updated version called The Real Mary Poppins and this time their advertising read as follows: 'This 2002 Documentary inspired the 2013 Hollywood film Saving Mr. Banks. . . We have in turn updated The Shadow of Mary Poppins, incorporating new footage including from Saving Mr. Banks and interviews with the stars of the film' (Aplin, 2014). Thus the backwash of the fiction infiltrates the biographical work.

Valerie Lawson's 1999 biography of Travers (republished in 2013 under a different title) also manifests signs of the father fixation that haunts Saving Mr. Banks. The book begins:

Helen Lyndon Goff had two fathers. One was real. The other she imagined. The traces of both men can be found in a third father, the completely fictional George Banks. . . Mr. Banks hired Mary Poppins to create order from that chaos, and, though he never went with her on one of her heavenly adventures, he knew instinctively that Mary Poppins was magic.

(1999, p. 4; 2013, p. 13).

Both as pop psychology and as a literary reading, this account is very thin. Mr. Banks did not actually hire Mary Poppins, his wife did; and in the books, he is for the most part oblivious to her magical ways. But the phase space of the Disney movie insists on reformable fathers as an essential ingredient in the Mary Poppins saga, and Lawson duly obliges in her 
biographical approach to the work, making such a theme essential to the author as well. In Lawson's account of Travers as auto-mythologiser, it is not entirely clear where the faultline lies between fiction and fact, nor is it always apparent which author - Lawson or Travers herself - should accept responsibility for some fuzzy biographical delineations. It is clear that Lawson uncovered considerable new information about Travers, but Jerry Griswold charges that 'the Lawson biography is sometimes unreliable in several ways. For instance, she sometimes engages in speculation and fictionalizes to make a story' (quoted in Reese, 2014).

The real Travers never endorsed the sentimental, improvable Banks. In the 1980s, she wrote, 'What wand was waved to turn Mr. Banks from a bank clerk into a minor president, from an anxious, ever-loving father into a man who could cheerfully tear into pieces a poem that his children had written?' (quoted in Flanagan, 2005, n.p.) Her Mr. Banks was simply a goodenough father by the standards of his time, from start to finish, no more and no less.

But for viewers, can the reform of Mr. Banks be un-imagined? Is it possible to extract the sugar of sentimental closure from a story once it has been injected into it? Even opinionated readers like myself, who single-mindedly favour the Travers account, must, after seeing the film, always thereafter read their preferred Mr. Banks against the Disney version. It is a process built into rhizomatic reception practices. 


\section{Other outcroppings}

The Mary Poppins commodities from the movie are largely schematic and uninteresting. The stage musical and the film of Saving Mr. Banks supply more intriguing spin-off material, in part because, in both cases, the time-honoured convention of supplying background material to the production itself ('the making of') addresses issues of fiction and metafiction in intriguing ways.

Sibley and Lassell (2007) present a tripartite background volume to explore aspects of the stage musical (published by Disney). A triptych hardcover opens up to reveal two paperback books, one attached to each side flap, framing an internal hardcover book. A design folio of conceptual drawings on the left hand is mirrored by a collection of photographs of the Broadway production on the right hand - in effect, two different workings of the same phasespace vision. The central hardcover volume tells 'the story of the journey from books to Broadway' (2007, p. 3). The stage play is a construct developed by many people and committees, and this unconventionally assembled work is devoted to an exploration of its artificiality. Where a single bound book may represent Pullman's linear path through the story, even the design of this artifact announces a more plural approach.

The background material for Saving Mr. Banks moves even further away from the unilinear world of the bound book. The Official Multi-Touch Book (Walt Disney, 2013) is an iBook about the creation of Saving Mr. Banks. It contains considerable multimedia archive material and numerous clips from the movie itself. There is plenty of room to explore the fault lines between the tape recordings of Travers and the Shermans (samples of which are supplied in 
the iBook's archive) and the fiction rendered from them. Multiple instantiations of Mary Poppins and at least two versions of P.L. Travers exist side by side as objects of interest here. But, strikingly, one monolith remains incorruptibly singular; the book says outright, 'Certainly, our world shall know but one Walt Disney' (2013, Chapter 2). They may have meant that he was too remarkable to happen twice, but a second meaning of "no place for plural interpretation' is also clearly established. The degree of control manifestly asserted over this particular Disney enterprise does not permit speculation about how the iconic figure of Walt was also created out of both fact and fiction. The Disney corporation is often happy to play fast and loose with phase space rules prior to its adapted version of a story taking hold. The company is much more rigorous at establishing a non-negotiable phase space for its own creations, once the changes are put in place. Thus Saving Mr. Banks makes no room for the faintest acknowledgement that P.L. Travers may sometimes have been right about the film of Mary Poppins. Viewers may read that interpretation into the story but the Official Multi-Touch Book is quick to eliminate any such possibility.

In the eyes of many of those who meet Mary Poppins first through the 1964 movie version, the idea that Mr. Banks might be a negligible character in the print saga is very difficult to absorb. Disney created a new phase space and then featured it as the unquestionable source of the issues driving Saving Mr. Banks. The idea that Mr. Banks constitutes a stand-in for Travers' own father is now a commonplace of the Travers story. 


\section{Rules and rhizomes}

Yet the books survive alongside the movie and the stage play. It is possible to resist Saving Mr. Banks, and many of its audience have done so. The rhizomatic landscape includes a variety of phase spaces but it also makes room for discrepant texts that disregard the rules of cohesiveness so clearly valued by Pullman (and by many others, often including Disney himself when his own text is the core story in question). In turn, it would not be impossible to imagine some texts developing a phase space that is itself rhizomatic, a phase space that makes room for internal contradictions in the originating materials.

Is it a component of contemporary cultural literacy to be able to accommodate numerous, sometimes contradictory rhizomatic outcroppings of a story? Do we need to learn to process story components that could be regarded as non-negotiable in a different version? Is fidelity still a reception issue? Different interpreters may have different thresholds for compromise and/or contradiction. We will all have an opportunity to test both the theories outlined in this article and our own tolerance for a new version of an old story when Disney releases a sequel movie called Mary Poppins Returns, currently scheduled for release on Christmas Day in 2018, more than 54 years after the first film's appearance (Kroll 2016, n.p.)

Neither the phase space nor the rhizome gives us a metaphorical key to understanding all of contemporary culture. The phase space provides language for the pleasures of the singular; the rhizome provides for the multiple, even the aggressively invasive forms of the multiple that refuse to work by the rules of the phase space. What they both do is remind us that many of today's most important stories now exist in plural and contradictory instantiations. Real- 
life interpreters sometimes fail to find satisfactory ways to make narrative or emotional sense of these inconsistencies. Children may be distressed by the incoherence of a plurality that adults may take for granted, or just dismiss, or simply dislike. And vice versa - children may be nonchalant about contradictions that seriously disconcert the adults in their lives.

When texts diverge, mutate, and/or develop lingering half-lives, there are consequences for reception. The voice of Kathryn Hughes, first delighted and then distressed by a new Mary Poppins, speaks for an element in the study of children's literature that merits careful attention. The phase space and the rhizome offer metaphors that may help to focus necessary perspectives on how reception is shaped in a literary landscape where versions of a story collide, collude, conflict, and survive in unruly juxtaposition.

\section{References}

Aplin, Brett (2014, January) 'The Shadow of Mary Poppins.' http://brettaplin.com.au/theshadow-of-mary-poppins/

Bird, Alan (2004, December) 'Mary Poppins at the Prince Edward Theatre.' LondonTheatre.co.uk https://www.londontheatre.co.uk/reviews/mary-poppins

Brantley, Ben (2006, November 17) 'Meddler on the Roof.' New York Times. http://www.nytimes.com/2006/11/17/theater/reviews/17popp.html?_r=0

Deleuze, Gilles and Félix Guattari. (1987) A Thousand Plateaus: Capitalism and Schizophrenia, trans. Brian Massumi. Minneapolis: University of Minnesota Press. 
Elick, Catherine L. (2001) 'Animal Carnivals: A Bakhtinian Reading of C. S. Lewis's The Magician's Nephew and P. L. Travers's Mary Poppins.' Style 35 (3): 454-470.

Flanagan, Caitlin (2005, December 19) 'Becoming Mary Poppins.' The New Yorker, http://www.newyorker.com/magazine/2005/12/19/becoming-mary-poppins

Hughes, Kathryn (2013, December 7) 'What Saving Mr Banks Tells Us about the Original Mary Poppins.' TheGuardian.com. http://www.theguardian.com/books/2013/dec/07/pl-travers-saving-mr-banks-original$\underline{\text { mary-poppins }}$

Hutcheon, Linda (2006) A Theory of Adaptation. New York: Routledge.

Kroll, Justin (2016, May 31) 'Disney Announces Release Date for 'Mary Poppins' Sequel.' Variety.com http://variety.com/2016/film/news/disney-announces-release-date-formary-poppins-sequel-1201785893/

Lawson, Valerie (1999) Out of the Sky She Came: The Extraordinary Life of P.L. Travers, Creator of Mary Poppins. Balmain, Australia: Hodder. Republished as Mary Poppins, She Wrote: The Life of P.L. Travers. London: Aurum, 2005; New York: Simon \& Schuster, 2013.

Levin, Donald (2007) 'The Americanization of Mary: Contesting Cultural Narratives in Disney's Mary Poppins,' in L. Stratyner and J.R. Keller (eds), Fantasy Fiction into Film: Essays. Jefferson, NC; McFarland; 2007, pp. 115-123.

Mackey, Margaret (1999) 'Playing in the Phase Space: Contemporary Forms of Fictional Pleasure.' Signal: Approaches to Children's Books 88: 16-33. 
Mackey, Margaret (2006) 'Inhabiting Anne's World: The Performance of a Story Space,' in F.M. Collins \& J. Ridgman (eds) Children's Literature in Performance and the Media. Oxford: Peter Lang, pp. 61-82.

Mary Poppins (2013/1964) Dir. Robert Stevenson. Walt Disney Productions. Burbank, CA: Buena Vista Home Entertainment. DVD.

Mary Poppins (December 15, 2004 - January 12, 2008) Dir. Richard Eyre. Pro. Disney and Cameron Mackintosh. Prince Edward Theatre, London. Stage play.

Mary Poppins (November 16, 2006 - March 3, 2013) Dir. Thomas Schumacher. Pro. Disney and Cameron Mackintosh. New Amsterdam Theatre. New York. Stage play.

Newman, Melinda (2013, December 19) 'Interview: Composer Richard Sherman on 'Saving Mr. Banks'.' Hitfix. (http://www.hitfix.com/news/interview-composerrichard-sherman-on-saving-mr-banks\#6516u6kguJwiM7fv.99

Overton, Scott (2016, May 6) ‘Theatre Cambrian’s Broadway Version of Mary Poppins Is Different but Spirited.' Sudbury.com https://www.sudbury.com/columns/theatrecambrians-broadway-version-of-mary-poppins-is-different-but-spirited-292041

Pearce, Sharyn (2015) 'The Business of Myth-Making: Mary Poppins, P.L. Travers and the Disney Effect.' Queensland Review 22 (1): 62-74.

Pullman, Philip (1998) 'Let's Write It in Red: The Patrick Hardy Lecture.' Signal: Approaches to Children's Books 85: 44-62.

Reese, Debbie (2014) 'Travers (author of Mary Poppins): 'I lived with the Indians...' American Indians in Children's Literature, 
http://americanindiansinchildrensliterature.blogspot.ca/2014/01/travers-author-ofmary-poppins-i-lived.html

Rochlin, Margy (2013, December 6) 'A Spoonful of Sugar for a Sourpuss.' New York Times.

Saving Mr. Banks (2014/2013) Dir. John Lee Hancock. Walt Disney Pictures. Burbank, CA: Buena Vista Home Entertainment. DVD.

Sherman, Robert B. and Richard M. Sherman. (1964) 'A Spoonful of Sugar.' In Mary Poppins. Walt Disney Productions. Song.

Sibley, Brian and Michael Lassell (2007) Mary Poppins: Anything Can Happen if You Let It: The Story behind the Journey from Books to Broadway. New York: Disney Editions.

Szumsky, Brian E. (2000) ““All That Is Solid Melts into the Air”: The Winds of Change and Other Analogues of Colonialism in Disney's Mary Poppins.' The Lion and the Unicorn 24 (1): 97-109.

Travers, P.L. (1965/1934) Mary Poppins. Illus. Mary Shepard. London: Collins.

Travers, P.L. (1953) The Magic Compass: A Story from 'Mary Poppins.' Illus. Gertrude Elliott. A Little Golden Book. New York: Simon and Schuster.

Travers, P.L. (2006/1962) Mary Poppins from A to Z. Illus. Mary Shepard. Orlando: Harcourt.

Travers, P.L. (2006/1975) Mary Poppins in the Kitchen. Illus. Mary Shepard. Orlando: Harcourt. 
Travers, P.L. (1999/1978) 'I Never Wrote for Children.' In A Lively Oracle: A Centennial Celebration of P.L. Travers, Creator of Mary Poppins, ed. E.D. Draper \& J. Koralek. New York: Larson Publications.

Travers, P.L. (2010) Mary Poppins: The Complete Collection. Illus. Mary Shepard. London: HarperCollins.

Walt Disney Studios (2013) Saving Mr. Banks: The Official Multi-Touch Book. Disney Publishing Worldwide. iBook.

\section{Biographical Note}

Margaret Mackey is Professor Emerita at the School of Library and Information Studies at the University of Alberta, currently phasing into retirement. She teaches and researches in the area of print and other literacies among young people. Her most recent book is One Child Reading: My Auto-Bibliography, published by the University of Alberta Press in 2016; it is a study of the print and media materials with which she herself became literate, as a child growing up in St. John's, Newfoundland, Canada, in the 1950s and early 1960s. Her newest research project involves an exploration of the role of landscape and setting on developing literacies. 